\title{
Essential oils activity from plants of the Brazilian Caatinga on the vegetable leafminer ${ }^{1}$
}

\author{
Andréa Costa Oliveira², Tiago Cardoso Costa-Lima ${ }^{3}$, \\ Ana Valéria Vieira Souza ${ }^{3}$, Rita de Cássia Rodrigues Gonçalves-Gervásio ${ }^{2}$
}

\section{ABSTRACT}

Liriomyza sativae (Blanchard) is a worldwide polyphagous pest for horticultural and ornamental crops, whose chemical control is the major method adopted. However, botanical insecticides in the form of essential oils (EOs) are presented as promising alternatives. This study aimed to evaluate the effect of EOs from the species Croton sonderianus Muell. Arg., Croton conduplicatus Kunth., Lippia gracilis Schauer and Lippia schaueriana Mart. on the biological aspects of L. sativae adults and immature stages (larva and pupa). The results showed larval and pupal mortality after the immersion of leaves with newly hatched $L$. sativae larvae in EOs solution from $L$. gracilis and L. schaueriana leaves. The EOs from C. conduplicatus stem bark and leaf and from C. sonderianus stem bark extended the leafminer pupal stage duration, while those from $C$. conduplicatus leaves and $C$. sonderianus stem bark decreased the oviposition and feeding punctures in nochoice tests. Only C. conduplicatus confirmed the effect in the free-choice test, showing to be the most promising in the study. This way, EOs from L. gracilis and L. schaueriana leaves show an insecticide activity on $L$. sativae larvae, and those from C. conduplicatus leaves reduce the leafminer oviposition and feeding punctures in melon plants.

KEYWORDS: Liriomyza sativae, Croton, Lippia, botanical insecticides, melon.

\section{INTRODUCTION}

The leafminer Liriomyza sativae Blanchard (Diptera: Agromyzidae) is a polyphagous pest of vegetables and ornamental plants, originally from the Americas; however, it is currently a global pest present in Africa, Europe, Asia and Oceania (CABI 2018).

The major damage is caused by its larvae, which feed internally in the leaves, forming galleries.

\section{RESUMO}

Atividade de óleos essenciais de plantas da Caatinga sobre a mosca-minadora

Liriomyza sativae (Blanchard) é uma praga polífaga de distribuição mundial em hortaliças e plantas ornamentais, cujo controle químico é o principal método adotado. Entretanto, inseticidas botânicos na forma de óleos essenciais (OEs) são apresentados como alternativas promissoras. Objetivou-se avaliar o efeito de OEs das espécies Croton sonderianus Muell. Arg., Croton conduplicatus Kunth., Lippia gracilis Schauer e Lippia schaueriana Mart. sobre aspectos biológicos de adultos e estágios imaturos (larva e pupa) de L. sativae. Os resultados demonstram mortalidade larval e pupal após imersão de folhas com larvas recémeclodidas de $L$. sativae em soluções de OEs de folhas de L. gracilis e L. schaueriana. Os OEs de casca e folha de C. conduplicatus e de casca de $C$. sonderianus prolongaram o período de pupa da mosca-minadora, enquanto os de folhas de C. conduplicatus e casca de $C$. sonderianus causaram redução na oviposição e puncturas de alimentação em testes de confinamento. Apenas $C$. conduplicatus confirmou o efeito no teste com livre chance de escolha, mostrandose como o mais promissor do estudo. Desta forma, OEs de folhas de L. gracilis e L. schaueriana possuem atividade inseticida sobre larvas de L. sativae e os de folhas de C. conduplicatus reduzem a oviposição e as puncturas de alimentação de mosca-minadora em meloeiro.

PALAVRAS-CHAVE: Liriomyza sativae, Croton, Lippia, inseticidas botânicos, melão.

Thus, there is a leaf area damage and, consequently, a photosynthetic activity reduction, resulting in a lower yield and fruit quality (Costa et al. 2017).

Chemical control is the major method adopted by producers; however, insecticide-resistant populations have been reported (Ferguson 2004, Wei 2015). Also, parasitoids are the major natural enemies of leafminers (Connor \& Taverner 1997), and several studies have shown the insecticides impact on these species (Matsuda \& Saito 2014, Guantai et al. 2015).

1. Received: Apr. 25, 2019. Accepted: July 19, 2019. Published: Dec. 11, 2019. DOI: 10.1590/1983-40632020v5058313.

2. Universidade Federal do Vale do São Francisco, Petrolina, PE, Brasil.E-mail/ORCID: andreaoliveira1@yahoo.com.br/ 0000-0001-9099-3541, rita.gervasio@univasf.edu.br/0000-0001-5171-6007.

3. Empresa Brasileira de Pesquisa Agropecuária (Embrapa Semiárido), Petrolina, PE, Brasil. E-mail/ORCID: tiago.lima@embrapa.br/0000-0002-4316-2806, ana.souza@embrapa.br/0000-0001-5399-0085. 
As an alternative for the synthetic chemical compounds, strategies are being studied in melon crops to control L. sativae, such as biological control with parasitoids (Costa-Lima et al. 2019), plant resistance (Celin et al. 2018) and botanical insecticides (Costa et al. 2018). The latter is based on plant materials, extracts or natural products derived from plants (Isman et al. 2011). Due to presenting a complex of substances that allow a greater interaction and acting on multiple targets, these products present a lower risk of selecting populations resistant to its compounds (Ntalli \& Menkissoglu-Spiroudi 2011). Among the botanical insecticides, Isman et al. (2011) suggest that plant essential oils (EOs) should become a popular choice for pest management. Among the positive aspects, the authors highlight that the EOs are generally non-toxic to mammals and environmentally non-persistent.

Biomes with a high biodiversity and low scientific exploration may be a good source for discovering new species that can act as botanical insecticides. The Caatinga, in northeastern Brazil, is the largest and most diverse neotropical seasonally dry tropical forest (Werneck et al. 2011). This biome has registered 4,657 seed plant species, with 913 (19.7\%) identified as endemic (Zappi et al. 2015). Among these endemic Caatinga plants, EOs from the Lippia and Croton genus have been studied for their chemical composition (Almeida et al. 2014, Souza et al. 2017a, Souza et al. 2017b, Souza et al. 2018). These studies showed the presence of compounds in these EOs that have been reported in the literature as presenting an insecticidal activity or effect on the insect behavior, such as carvacrol (Bagul et al. 2018), piperitone oxid (Grudniewska et al. 2011), eucalyptol (Moretti et al. 2015) and $\alpha$-pinene (Haselton et al. 2015).

Thus, this study aimed to evaluate the effect of EOs from the species Croton sonderianus Muell. Arg. (leaves and stem bark), Croton conduplicatus Kunth. (leaves and stem bark), Lippia gracilis Schauer (leaves) and Lippia schaueriana Mart. (leaves) on L. sativae adults and immature stages (larvae and pupae) biological aspects.

\section{MATERIAL AND METHODS}

L. gracilis and L. schaueriana leaves and C. sonderianus and C. conduplicatus leaves and stem barks were collected in Petrolina (Pernambuco state,
Brazil), respectively in the coordinates $09^{\circ} 23^{\prime} 35^{\prime \prime} \mathrm{S}$ and $40^{\circ} 30^{\prime} 27^{\prime \prime} \mathrm{W}$; $09^{\circ} 09^{\prime} \mathrm{S}$ and $40^{\circ} 22^{\prime} \mathrm{W}$; $09^{\circ} 07^{\prime}{ }^{\prime} 17^{\prime \prime} \mathrm{S}$ and 40 31'9'W; 09 03 '54"S and 40'19'12'"W. The Lippia spp. vegetative structures were collected in December 2011 and the Croton spp. samples between July and September 2012. The essential oils were obtained according to Souza et al. (2017a).

The identification of compounds present in the EOs samples used in this study was previously published for the following species: $C$. sonderianus leaves (Souza et al. 2017a), C. conduplicatus leaves (Almeida et al. 2014) and stem barks (Oliveira et al. 2017), L. gracilis leaves (Souza et al. 2017b) and L. schaueriana leaves (Souza et al. 2018). For the $C$. sonderianus stem barks EOs, the identification of major compounds was performed in the present study. In this case, the EOs chemical composition was determined by gas-phase chromatography coupled to mass spectrometer (GCMS), in a Shimadzu chromatograph GC-2010 Plus, GCMS-QP2010 Ultra equipped with an automatic sampler AOC model-20i (Souza et al. 2017a) and also by gas chromatography coupled to a flame ionization detector (GC-DIC), in a gas chromatograph $\operatorname{Varian}^{\circledR}$ CP-3380 equipped with DIC.

Initially, L. sativae larvae were obtained in melon leaves in Juazeiro (Bahia state), northeastern Brazil (9'36'35.4'S and 40'33'56.2'W). The species was reared in laboratory on cowpea plants [Vigna unguiculata (L.) Walp.] (Costa-Lima et al. 2010).

The melon plants used in the experiments were from the yellow type, "Gladial" variety. In a greenhouse, the seeds were weekly sown in a 200cell tray containing Plantmax ${ }^{\circledR}$ commercial substrate. The seedlings were transplanted to cups $(500 \mathrm{~mL})$ containing sand and organic fertilizer $(1: 1)$. When the melon plants achieved two permanent completely expanded leaves (approximately 20 days after sowing), the plants were offered to $L$. sativae adults in breeding cages for $24 \mathrm{~h}$. Afterwards, the plants were transferred to climatic chambers $\left(25 \pm 1{ }^{\circ} \mathrm{C}, \mathrm{RH}\right.$ of $50 \pm 20 \%$ and $12 \mathrm{~L}: 12 \mathrm{D}$ photoperiod). After three days, the newly hatched larvae were counted under a stereoscopic microscope (40x) with transmitted light.

The treatments were evaluated with the following EOs: (i) L. gracilis leaves; (ii) L. schaueriana leaves; (iii) C. sonderianus leaves; (iv) C. sonderianus stem bark; (v) C. conduplicatus leaves; (vi) C. conduplicatus stem bark. The EOs concentration was $1,000 \mathrm{ppm}$, dissolved in distilled water with dimethyl sulfoxide (DMSO) $1 \%$. The control was 
composed by $1 \%$ DMSO. This solvent was chosen for not causing phytotoxicity, while others, as acetone, provoked leaf chlorosis and distortion.

The bioassay to assess the insecticide potential on the larval phase was adapted from Ferguson (2004). For each treatment, leaves with $L$. sativae larvae with less than $24 \mathrm{~h}$ were immersed for $5 \mathrm{~s}$ in the different solutions. After the immersion, the plants remained at room temperature for drying the leaves. Then, the plants were kept in climatic chambers $(25 \pm$ $1{ }^{\circ} \mathrm{C}, \mathrm{RH}$ of $50 \pm 20 \%$ and $12 \mathrm{~L}: 12 \mathrm{D}$ photoperiod).

The biological parameters evaluated were larval and pupal mortality and pupal duration. The larvae were daily evaluated using a stereoscopic microscope $(40 \mathrm{x})$. The newly formed pupae were transferred to Petri dishes $(6 \mathrm{~cm} \varnothing)$ coated with plastic film. In this step, the pupal viability and duration were calculated.

For the free-choice test, the EOs used were the same as in the previous experiment, with a $500 \mathrm{ppm}$ concentration. The solutions were transferred to a prior compression sprayer $(2 \mathrm{~L})$. Melon plants with approximately 15 days after seeding were subjected to the respective treatments by spraying to run-off. The control treatment was composed of DMSO $1 \%$. After the evaporation of the moisture excess, the plants were kept in cages with screen mesh sides (40 $\mathrm{cm} \times 39 \mathrm{~cm}$ for base and height of $50 \mathrm{~cm}$ ). For the bioassay, two plants were placed in a cage, being one treated with EOs and the other only with DMSO $1 \%$. A honey solution (10\%) was provided as an adult food source. The treatments were kept in a controlled temperature room $\left(25 \pm 2{ }^{\circ} \mathrm{C}\right.$, RH of $50 \pm$ $20 \%$ and $12 \mathrm{~L}: 12 \mathrm{D}$ photoperiod). Inside each cage, five $L$. sativae females were released (4-6 days old), which remained in contact with the plants for $24 \mathrm{~h}$. The age range of the females was chosen based on the higher L. sativae oviposition rate period (CostaLima et al. 2010). After this period, the eggs and feeding punctures were counted under a stereoscopic microscope (90x) with transmitted light. In the nochoice bioassay, the method was similar to the one previously reported. However, in each cage, only one plant sprayed with a single treatment was maintained.

For the EOs insecticidal activity bioassay, the experimental design was completely randomized. Each insect was considered a replicate, ranging from 61 to 130 larvae and 59 to 117 pupae per treatment. Non-generalized linear models with quasi-binomial distribution for the larvae and pupae mortality data analysis were used. When there was a significant difference between the treatments, multiple comparisons (Tukey test; $p<0.05$ ) were carried out by means of the function glht multicomp package, with adjustment of the $\mathrm{p}$ values. For the pupal duration, the averages and standard errors were defined by the Kaplan-Meier estimator (Kaplan \& Meier 1958). Pairwise comparisons between the group levels were done using the log-rank test, with the pairwise_survdiff() function of the survminer package $(\mathrm{p}<0.05)$.

The bioassays to evaluate the L. sativae oviposition and feeding had an experimental randomized block design. Each cage was considered a replicate, totalling 11 replicates for the free-choice test and six for the no-choice test. For the free-choice test data comparison, the F-test was applied at $5 \%$ of significance. The no-choice data were subjected to analysis of variance and Tukey test $(\mathrm{p}<0.05)$.

All analyses were performed using the $\mathrm{R}$ statistical software, version 3.5.2 (R Development Core Team 2018), and the graphic presentations using the SigmaPlot (2019) software, version 5.6 (Systat Software Inc., Chicago, II, USA).

\section{RESULTS AND DISCUSSION}

The L. gracilis and L. schaueriana leaves EOs presented an insecticide effect on the L. sativae larval stage, while the treatments composed by the Croton species did not differ from the control. The pupae originated from larvae exposed to L. gracillis EOs also had a lower viability. Considering the overall L. sativae mortality (larvae and pupae), L. gracillis and $L$. schaueriana reached a mean of $47.72 \%$ and $45.71 \%$, respectively (Table 1 ).

This is the first report of Lippia EOs with insecticide activity on leafminer insects. Several authors have reported the activity of L. gracillis EOs on other arthropods, such as Lepidoptera larvae (Melo et al. 2018), mosquitoes (Maia et al. 2008) and ticks (Cruz et al. 2013). Regarding L. schaueriana, this was the first insecticidal activity record. Other Lippia species also have shown insecticidal effect on arthropods; for example, Lippia alba (Mill.) (Peixoto et al. 2015), Lippia pedunculosa (Hayek) (Nascimento et al. 2017) and Lippia origanoides (Kunth) (Castillo et al. 2017).

The main compounds present in the $L$. gracillis EOs were carvacrol $(78.6 \%)$ and thymol $(6.3 \%)$ 
Table 1. Mortality (mean \pm standard error) rate for Liriomyza sativae larvae, pupae and total (larvae + pupae), after the immersion of melon leaves with newly hatched larvae in essential oils solutions (1,000 ppm) and control (DMSO $1 \%$ ).

\begin{tabular}{lccc}
\hline \multirow{2}{*}{ Treatment } & \multicolumn{3}{c}{ Mortality (\%) } \\
\cline { 2 - 4 } & Larvae & Pupae & Total \\
\hline Lippia gracilis (leaf) & $27.27 \pm 2.90 \mathrm{a} \mathrm{a}^{1}$ & $28.12 \pm 5.66 \mathrm{a}$ & $47.72 \pm 5.35 \mathrm{a}$ \\
Lippia schaueriana (leaf) & $30.00 \pm 3.58 \mathrm{a}$ & $22.45 \pm 6.02 \mathrm{ab}$ & $45.71 \pm 5.99 \mathrm{a}$ \\
Croton conduplicatus (stem) & $15.60 \pm 1.31 \mathrm{ab}$ & $21.00 \pm 3.75 \mathrm{ab}$ & $33.33 \pm 3.98 \mathrm{ab}$ \\
Croton sonderianus (leaf) & $14.67 \pm 4.11 \mathrm{ab}$ & $21.87 \pm 5.20 \mathrm{ab}$ & $34.66 \pm 5.53 \mathrm{~b}$ \\
Croton sonderianus (stem) & $12.21 \pm 1.06 \mathrm{ab}$ & $8.69 \pm 2.64 \mathrm{~b}$ & $19.84 \pm 3.49 \mathrm{~b}$ \\
Croton conduplicatus (leaf) & $3.28 \pm 2.29 \mathrm{~b}$ & $16.95 \pm 4.27 \mathrm{ab}$ & $19.67 \pm 5.13 \mathrm{~b}$ \\
Control & $10.20 \pm 0.51 \mathrm{~b}$ & $11.65 \pm 1.71 \mathrm{~b}$ & $20.66 \pm 2.06 \mathrm{~b}$ \\
\hline
\end{tabular}

Averages with different letters in the same column differ by the Tukey test $(\mathrm{p}<0.05)$.

(Souza et al. 2017b). The L. sativae larval mortality is probably associated with a high concentration of carvacrol. This monoterpene is reported as toxic to agricultural and veterinary importance insects (Cruz et al. 2013, Park et al. 2017). Tong \& Coats (2010) studied the carvacrol mode of action on Musca domestica L. and Periplaneta americana L. and showed the compound action as a positive allosteric modulator in the gamma-aminobutyric acid (GABA) receptor, the major inhibitory neurotransmitter in the central and peripheral insects nervous system. Thus, providing a chloride mediated by GABA increases the uptake and consequent inhibition in the nervous system and the death of insects.

For L. schaueriana leaves EOs, the chromatographic analysis identified as major compounds the piperitone oxide $(73.5 \%)$ and limonene $(8.0 \%)$ (Souza et al. 2018). For both the compounds, there are reports of toxicity on insects (Kim \& Lee 2014, Momen et al. 2018). Mentha microphylla K. Koch EOs containing high piperitone oxide concentrations caused mortality in Sitophilus oryzae and Tribolium castaneum adults (Mohamed \& Abdelgaleil 2008). Another species with a high level of the same compound, Plectranthus mollis (Aiton) Spreng. (Lamiaceae), showed a larvicidal activity on mosquitoes of medical importance (Kulkarni et al. 2013). Similarly to our study, the larvicidal activity has already been observed in other Lippia plants (i.e., L. pedunculosa), which presented deleterious effects on Aedes aegypti (L.) larvae (Nascimento et al. 2017).

Regarding Croton EOs, no larval mortality effect was observed on L. sativae. However, the pupae originated from the larvae pre-exposed to $C$. conduplicatus (leaves and stems) and C. sonderianus (stems) EOs presented a prolonged duration, if compared to the control $(\mathrm{p}<0.05)$
(Table 2). Many EOs and their constituents may cause these effects, such as alteration in the development period (Park \& Tak 2016). Citrus limonum (L.) and Litsea cubeba (Lour.) EOs are examples on Tenebrio molitor L., which resulted in prolonging the egg and larval period and shortening the beetle pupal phase (Wang et al. 2015). The authors identified $\beta$-pinene as one of the major compounds on the $C$. limonum EO. For C. conduplicatus stem bark EO, that caused elongation on the $L$. sativae pupal phase, $\beta$-pinene was also one of the main compounds (Oliveira et al. 2017).

In the present study, it was also possible to verify other effects on L. sativae in the EOs treatments, among these the darkened and dry pupae formation and adults with deformities. Probably, the EOs caused physiological changes that interfered in the insect metamorphosis. Similar alterations were observed in $M$. domestica pupae treated with monoterpenes, that showed a high incomplete emergence and adult malformation (Kumar et al. 2014).

In the free-choice test, the melon plants sprayed with $C$. conduplicatus leaves EO showed a

Table 2. Liriomyza sativae pupal stage duration (mean \pm standard error), after the immersion of melon leaves with leafminer larvae in essential oils solutions $(1,000 \mathrm{ppm})$ and control (DMSO $1 \%)\left(25 \pm 1{ }^{\circ} \mathrm{C} ; 50 \pm 20 \%\right.$ of RH; $\left.12 \mathrm{~h}\right)$.

\begin{tabular}{lc}
\hline \multicolumn{1}{c}{ Treatment } & Pupa duration (days) \\
\hline Croton conduplicatus (stem) & $10.11 \pm 0.08 \mathrm{a}^{1}$ \\
Croton conduplicatus (leaf) & $9.69 \pm 0.08 \mathrm{~b}$ \\
Croton sonderianus (stem) & $9.61 \pm 0.05 \mathrm{~b}$ \\
Lippia gracilis (leaf) & $9.39 \pm 0.08 \mathrm{bc}$ \\
Croton sonderianus (leaf) & $9.20 \pm 0.11 \mathrm{c}$ \\
Lippia schaueriana (leaf) & $9.05 \pm 0.12 \mathrm{c}$ \\
Control & $9.34 \pm 0.04 \mathrm{c}$ \\
\hline
\end{tabular}

${ }^{1}$ Means and standard errors were defined by the Kaplan-Meier estimator; thus, means without a common letter differ by the Log-rank test $(\mathrm{p}<0.05)$. 
2.7-fold lower number of eggs, when compared to the control (Figure 1A). For all the other treatments, no effect was observed on the L. sativae oviposition. The leafminer feeding preference was also not affected by the EOs spraying (Figure 1B).

In the no-choice test, the $C$. conduplicatus leaves also showed the best result, reducing in 20fold the oviposition, if compared to the control. The C. sonderianus stem EO also caused a reduction in the number of eggs in 5.8-fold. Regarding the feeding punctures, four treatments with EOs presented a lower mean than the control: C. conduplicatus (leaf), C. sonderianus (stem and leaf) and L. gracillis (leaf) (Table 3).

In the bioassays with $L$. sativae adults, the C. conduplicatus leaves and $C$. sonderianus stems EOs probably provoked a repellent and/or deterrent action. The Croton roxburghii Balakr EO caused repellence to mosquitoes from the genus Armigeres, Culex and Aedes (Vongsombath et al. 2012). The Croton malambo (Karst) EO also caused repellence to the coleopteran Tribolium castaneum (Herbst.) (Jaramillo-Colorado et al. 2014).

The majority of the compounds present in the $C$. conduplicatus leaves EOs were 1-8-cineole (eucalyptol) (15.88\%), p-cymene (11.38\%) and spathulenol (11.23\%) (Almeida et al. 2014). Eucalyptol has been known for its insects repellence since the 1980's, from tests on P. americana (Scriven \& Meloan 1984) and for A. aegypti (Klocke et al. 1987). The same compound caused deterrence on the beetle T. castaneum (Tripathi et al. 2001) and reduced the two-spotted spider mite oviposition (Roh et al. 2013). Thus, it is possible that eucalyptol also shows a repellent and/or deterrent action on L. sativae. Sensory cells located on the antennas must be related to stimulus detection, as already observed in L. sativae, in response to Dolichandrone caudafelina (Hance) Benth. \& Hook EO (Habita et al. 2007). For the mosquito Culex quinquefasciatus Say, a short antennal trichoid sensilla was identified, with a high sensitivity to eucalyptol (Syed \& Leal 2008).

Table 3. Means ( \pm standard error) for the number of eggs of Liriomyza sativae and feeding punctures in melon plants sprayed with essential oil solutions (500 ppm) and control (DMSO $1 \%$ ), in a no-choice test.

\begin{tabular}{lcc}
\hline \multicolumn{1}{c}{ Treatment } & Eggs & Feeding punctures \\
\hline C. conduplicatus (leaf) & $0.17 \pm 0.17 \mathrm{a}^{1}$ & $85.67 \pm 17.52 \mathrm{a}$ \\
C. sonderianus (stem) & $5.83 \pm 2.15 \mathrm{~b}$ & $115.00 \pm 26.69 \mathrm{ab}$ \\
C. sonderianus (leaf) & $13.5 \pm 2.29 \mathrm{bc}$ & $213.67 \pm 50.20 \mathrm{ab}$ \\
L. gracilis (leaf) & $16.33 \pm 3.07 \mathrm{c}$ & $220.50 \pm 24.79 \mathrm{~b}$ \\
C. conduplicatus (stem) & $19.67 \pm 4.01 \mathrm{c}$ & $325.33 \pm 37.18 \mathrm{bc}$ \\
L. schaueriana (leaf) & $24.17 \pm 1.54 \mathrm{c}$ & $328.33 \pm 41.05 \mathrm{bc}$ \\
Control & $34.33 \pm 8.27 \mathrm{c}$ & $413.33 \pm 60.22 \mathrm{c}$ \\
\hline
\end{tabular}

${ }^{1}$ Means followed by the same letter do not differ by the Tukey test $(\mathrm{p}<0.05)$.
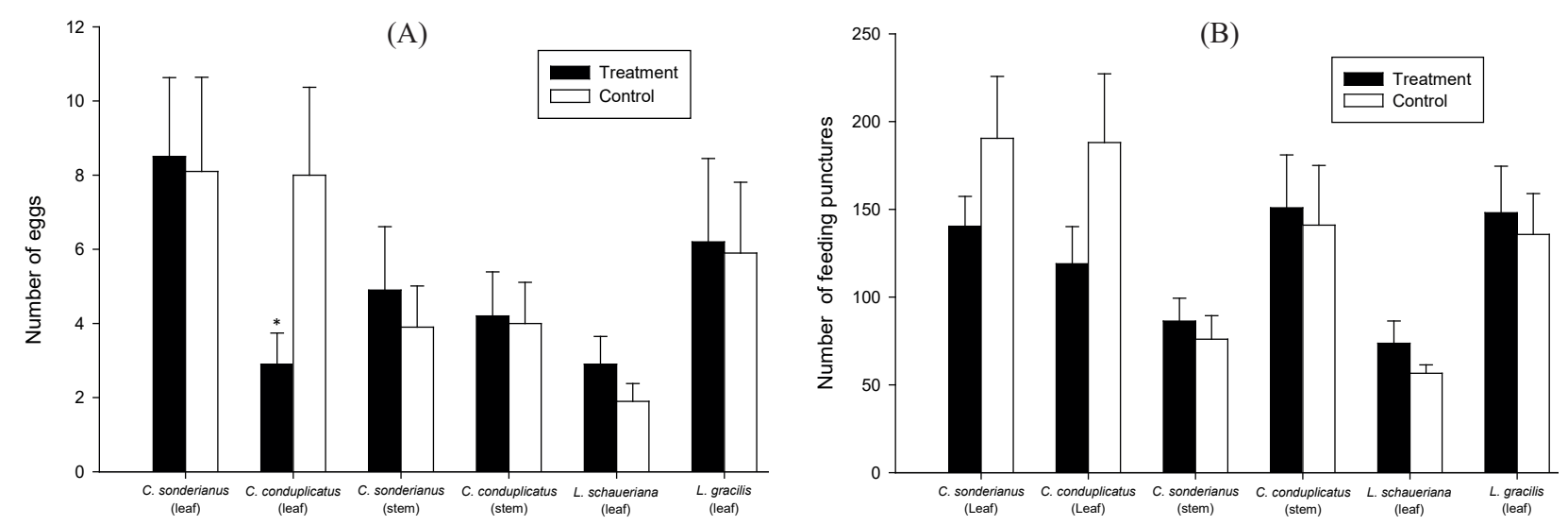

Figure 1. Means for number of Liriomyza sativae eggs (A) and feeding punctures (B) in melon plants treated with essential oils $(500 \mathrm{ppm})$ and control (DMSO $1 \%$ ), after $24 \mathrm{~h}$ of exposure in a free-choice test. Bars above each column are the standard error of the mean. * Significant contrast "treatment $v s$. control" by the F-test at $5 \%$ of probability. 
The other two C. conduplicatus leaves EO main compounds, p-cymene and spathulenol (Almeida et al. 2014), are also reported as repellents for mosquitoes (Park et al. 2005). Probably all these main compounds are involved in the L. sativae oviposition drastic reduction observed in our results. For the $C$. sonderianus stems EO, which also caused a reduction in the L. sativae oviposition in the no-choice test, the main compound identified was $\alpha$-pinene $(42.14 \%)$. This terpene is known as mosquito (Nerio et al. 2010) and M. domestica repellent (Haselton et al. 2015).

The present study brought new information on EOs of plants from the Caatinga biome, species with few studies or still not explored. A leafminer insect as a pest target must also be highlighted, considering the restricted reports of the EOs action over this insect guild. Nowadays, Azadirachta indica A. Juss. is the only botanical insecticide commercialized in Brazil to control leafminers (Agrofit 2019), showing the demand for new products in this area. Promising results, mainly related to the L. sativae oviposition reduction by $C$. conduplicatus leaves EOs, demonstrate the potential as a management strategy for this pest. Therefore, it is important the research continuity to detect the compounds involved in the effects, thus allowing to develop new products with a greater efficiency and less impact on the environment.

\section{CONCLUSION}

Essential oils from Lippia gracilis and Lippia schaueriana leaves show insecticide effect over Liriomyza sativae larvae, and the former also reduces the pupae viability, while the essential oil from Croton conduplicatus leaves reduces the L. sativae oviposition.

\section{REFERENCES}

AGROFIT: sistema de agrotóxicos fitossanitários. 2019. Available at: http://extranet.agricultura.gov.br/agrofit cons/principal_agrofit_cons. Access on: July 25, 2019.

ALMEIDA, J.; SOUZA, A. V.; OLIVEIRA; A. P.; SANTOS, U.; SOUZA, M.; BISPO, L.; TURATTI, Z. C.; LOPES, N. Chemical composition of essential oils from Croton conduplicatus (Euphorbiaceae) in two different seasons. Journal of Essential Oil-Bearing Plants, v. 17, n. 6, p. 1137-1145, 2014.
BAGUL, S. D.; RAJPUT, J. D.; SRIVASTAVA, C.; BENDRE, R. S. Insect growth regulatory activity of carvacrol-based 1,3,4-thiadiazoles and 1,3,4-oxadiazoles. Molecular Diversity, v. 22, n. 3, p. 647-655, 2018.

CABI. Invasive species compendium. 2018. Available at: https://www.cabi.org/isc/datasheet/30960. Access on: Apr. 5, 2019.

CASTILlO, R. M.; STASHENKO, E.; DUQUE, J. E. Insecticidal and repellent activity of several plantderived essential oils against Aedes aegypti. Journal of the American Mosquito Control Association, v. 33, n. 1, p. 25-35, 2017.

CELIN, E. F.; OLIVEIRA, N. R. X.; SILVA, F. D.; OLIVEIRA, V. R.; ARAGAO, F. A. S. A915.34.01.08: melon line resistant to leafminer (Liriomyza sativae). Crop Breeding and Applied Biotechnology, v. 18, n. 2, p. 215-220, 2018.

CONNOR, E. F.; TAVERNER, M. P. The evolution and adaptive significance of the leaf-mining habit. Oikos, v. 79, n. 1, p. 6-25, 1997.

COSTA, E. M. Determinação da área foliar danificada e de respostas fisiológicas do meloeiro frente à infestação de Liriomyza sativae. Horticultura Brasileira, v. 35, n. 4, p. 571-575, 2017.

COSTA, E. M.; SILVA, F. E. L.; ARAÚJO, E. L. Effect of aqueous neem seed extract via irrigation on larvae of Liriomyza sativae in melon crop. Horticultura Brasileira, v. 36, n. 3, p. 353-356, 2018.

COSTA-LIMA, T. C.; CHAGAS, M. C. M.; PARRA, J. R. P. Comparing potential as biocontrol agents of two neotropical parasitoids of Liriomyza sativae. Neotropical Entomology, v. 48, n. 4, p. 660-667, 2019.

COSTA-LIMA, T. C.; GEREMIAS, L. D.; PARRA, J. R. P. Reproductive activity and survivorship of Liriomyza sativae (Diptera: Agromyzidae) at different temperatures and relative humidity levels. Environmental Entomology, v. 39, n. 1, p. 195-201, 2010.

CRUZ, E. M. O.; COSTA JUNIOR, L. M.; PINTO, J. A.; SANTOS, D. A.; ARAUJO, S. A.; ARRIGONIBLANK, M. F.; BACCI, L.; ALVES, P. B.; CAVALCANTI, S. C.; BLANK, A. F. Acaricidal activity of Lippia gracilis essential oil and its major constituents on the tick Rhipicephalus (Boophilus) microplus. Veterinary Parasitology, v. 195, n. 1-2, p. 198-202, 2013.

FERGUSON, J. S. Development and stability of insecticide resistance in the leafminer Liriomyza trifolii (Diptera: Agromyzidae) to cyromazine, abamectin, and spinosad. Journal of Economic Entomology, v. 97, n. 1, p. 112-119, 2004.

GRUDNIEWSKA, A.; DANCEWICZ, K.; BIAŁOŃSKA, A.; CIUNIK, Z.; GABRYŚ, B.; WAWRZEŃCZYK, C. 
Synthesis of piperitone-derived halogenated lactones and their effect on aphid probing, feeding, and settling behavior. RSC Advances, v. 1, n. 1, p. 498-510, 2011.

GUANTAI, M. M.; OGOL, C. P.; SALIFU, D.; KASINA, J. M.; AKUTSE, K. S.; FIABOE, K. K. Differential effects of pesticide applications on Liriomyza huidobrensis (Diptera: Agromyzidae) and its parasitoids on pea in central Kenya. Journal of Economic Entomology, v. 108, n. 2, p. 662-671, 2015.

HABITA, A.; YONG-YUE, L.; LING, Z. Deterrent effect of essential oil extracted from Dolichandrone cauda-felina on oviposition of Liriomyza sativae Blanchard (Diptera: Agromyzidae). Joumal of South China Agricultural University, v. 28, n. 1, p. 58-62, 2007.

HASELTON, A. T.; ACEVEDO, A.; KURUVILLA, J.; WERNER, E.; KIERNAN, J.; DHAR, P. Repellency of $\alpha$-pinene against the house fly, Musca domestica. Phytochemistry, v. 117, n. 1, p. 469-475, 2015.

ISMAN, M. B.; MIRESMAILLI, S.; MACHIAL, C. Commercial opportunities for pesticides based on plant essential oils in agriculture, industry and consumer products. Phytochemistry Reviews, v. 10, n. 2, p. 197204, 2011.

JARAMILLO-COLORADO, B. E.; KAREN, M. C.; EDISSON, D. R.; ELENA, S.; JESUS, O. V. Volatile secondary metabolites from Colombian Croton malambo (Karst) by different extraction methods and repellent activity of its essential oil. Journal of Essential OilBearing Plants, v. 17, n. 5, p. 992-1001, 2014.

KAPLAN, E. L.; MEIER, P. Nonparametric estimation from incomplete observations. Journal of the American Statistical Association, v. 53, n. 282, p. 457-481, 1958.

KIM, S. I.; LEE, D. W. Toxicity of basil and orange essential oils and their components against two coleopteran stored products insect pests. Journal of Asia-Pacific Entomology, v. 17, n. 1, p. 13-17, 2014.

KLOCKE, J. A.; DARLINGTON, M. V.; BALANDRIN, M. F. 1,8-cineole (eucalyptol), a mosquito feeding and ovipositional repellent from volatile oil of Hemizonia fitchii (Asteraceae). Journal of Chemical Ecology, v. 13, n. 12, p. 2131-2141, 1987.

KULKARNI, R. R.; PAWAR, P. V.; JOSEPH, M. P.; AKULWAD, A. K.; SEN, A.; JOSHI, S. P. Lavandula gibsoni and Plectranthus mollis essential oils: chemical analysis and insect control activities against Aedes aegypti, Anopheles sfttephensi and Culex quinquefasciatus. Journal of Pest Science, v. 86, n. 4, p. 713-718, 2013.

KUMAR, P.; MISHRA, S.; MALIK, A.; SATYA, S. Biocontrol potential of essential oil monoterpenes against housefly, Musca domestica (Diptera: Muscidae).
Ecotoxicology and Environmental Safety, v. 100, n. 1, p. 1-6, 2014.

MAIA, R. T.; DÓRIA, G. A.; MAIA, R. T.; NUNES, R. S.; CARVALHO, G. A.; BLANK, A. F.; ALVES, P. B.; MARÇAL, R. M.; CAVALCANTI, S. C. Effects of essential oils on Aedes aegypti larvae: alternatives to environmentally safe insecticides. Bioresource Technology, v. 99, n. 8, p. 3251-3255, 2008.

MATSUDA, K.; SAITO, T. Insecticide susceptibility and carboxylesterase activity in leafminers (Diptera: Agromyzidae) and their associated hymenopteran parasitoids. Crop Protection, v. 55, n. 1, p. 50-54, 2014.

MELO, C. R.; PICANÇO, M. C.; SANTOS, A. A.; SANTOS, I. B.; PIMENTEL, M. F.; SANTOS, A. C. C.; BLANK, A. F.; ARAÚJO, A. P. A.; CRISTALDO, P. F.; BACCI, L. Toxicity of essential oils of Lippia gracilis chemotypes and their major compounds on Diaphania hyalinata and non-target species. Crop Protection, v. 104, n. 1, p. 47-51, 2018.

MOHAMED, M. I. E.; ABDELGALEIL, S. A. M. Chemical composition and insecticidal potential of essential oils from Egyptian plants against Sitophilus oryzae (L.) (Coleoptera: Curculionidae) and Tribolium castaneum (Herbst) (Coleoptera: Tenebrionidae). Applied Entomology and Zoology, v. 43, n. 4, p. 599-607, 2008.

MOMEN, F. M.; ABDELKADER, M. M.; FAHIM, S. F. Composition, repellent and fumigant toxicity of Mentha longifolia essential oil on Tetranychus urticae and three predatory mites of the family phytoseiidae (Acari: Tetranychidae: Phytoseiidae). Acta Phytopathologica et Entomologica Hungarica, v. 53, n. 2, p. 221-232, 2018.

MORETTI, A. N.; ZERBA, E. N.; ALZOGARAY, R. A. Lethal and sublethal effects of eucalyptol on Triatoma infestans and Rhodnius prolixus, vectors of Chagas disease. Entomologia Experimentalis et Applicata, v. 154, n. 1, p. 62-70, 2015.

NASCIMENTO, A. M. D.; MAIA, T. D.; SOARES, T. E.; MENEZES, L. R.; SCHER, R.; COSTA, E. V.; CAVALCANTI, S. C.; LA CORTE, R. Repellency and larvicidal activity of essential oils from Xylopia laevigata, Xylopia frutescens, Lippia pedunculosa, and their individual compounds against Aedes aegypti Linnaeus. Neotropical Entomology, v. 46, n. 2, p. 223-230, 2017.

NERIO, L. S.; OLIVERO-VERBEL, J.; STASHENKO, E. Repellent activity of essential oils: a review. Bioresource Technology, v. 101, n. 1, p. 372-378, 2010.

NTALLI, N. G.; MENKISSOGLU-SPIROUDI, U. Pesticides of botanical origin: a promising tool in plant protection. In: STOYTCHEVA, M. (ed.). Pesticides: formulations, effects, fate. Ensenada: Intechopen, 2011. p. 1-24. 
OLIVEIRA, R. G. de; FERRAZ, C. A. A.; SILVA, J. C.; OlIVEIRA, A. P. de; DINIZ, T. C.; SILVA, M. G.; QUINTANS JÚNIOR, L. J.; SOUZA, A. V. V. de; SANTOS, U. S. dos; TURATTI, I. C. C.; LOPES, N. P.; LORENZO, V. P.; ALMEIDA, J. R. G. D. S. Antinociceptive effect of the essential oil from Croton conduplicatus Kunth (Euphorbiaceae). Molecules, v. 22, n. 6, p. 1-11, 2017.

PARK, A. B.; CHOI, W. S.; KIM, J. H.; KIM, K. H.; LEE, S. E. Monoterpenes from Thyme (Thymus vulgaris) as potential mosquito repellents. Journal of the American Mosquito Control Association, v. 21, n. 1, p. 80-83, 2005.

PARK, J. H.; JEON, Y. J.; LEE, C. H.; CHUNG, N.; LEE, H. S. Insecticidal toxicities of carvacrol and thymol derived from Thymus vulgaris L. against Pochazia shantungensis Chou \& Lu., newly recorded pest. Scientific Reports, v. 7, n. 1, p. 1-7, 2017.

PARK, Y. L.; TAK, J. H. Essential oils for arthropod pest management in agricultural production systems. In: PREEDY, V. R. (ed.). Essential oils in food preservation, flavor and safety. London: Elsevier, 2016. p. 61-70.

PEIXOTO, M. G.; BACCI, L.; BLANK, A. F.; ARAÚJO, A. P. A.; ALVES, P. B.; SILVA, J. H. S.; SANTOS, A. A.; OLIVEIRA, A. P.; COSTA, A. S. da; ARRIGONIBLANK, M. F. Toxicity and repellency of essential oils of Lippia alba chemotypes and their major monoterpenes against stored grain insects. Industrial Crops and Products, v. 71, n. 1, p. 31-36, 2015.

R DEVELOPMENT CORE TEAM. $R$ : a language and environment for statistical computing. Vienna: R Foundation for Statistical Computing, 2018.

ROH, H. S.; LEE, B. H.; PARK, C. G. Acaricidal and repellent effects of myrtacean essential oils and their major constituents against Tetranychus urticae (Tetranychidae). Journal of Asia-Pacific Entomology, v. 16, n. 3, p. 245249, 2013.

SCRIVEN, R.; MELOAN, C. E. Determining the active component in 1, 3, 3-trimethyl-2-oxabicyclo $\{2,2,2\}$ octane (cineole) that repels the American cockroach, Periplaneta americana. The Ohio Journal of Science, v. 84, n. 3, p. 85-88, 1984.

SIGMAPLOT. San Jose: Systat Software Inc., 2019.

SOUZA, A. V. V. de; BRITTO, D. de; SANTOS, U. S. dos; BISPO, L. dos P.; TURATTI, T. C. C.; LOPES, N. P.; OLIVEIRA, A. P. de; ALMEIDA, J. R. G. da S. Influence of season, drying temperature and extraction time on the yield and chemical composition of 'marmeleiro' (Croton sonderianus) essential oil. Journal of Essential Oil Research, v. 29, n. 1, p. 76-84, 2017 a.
SOUZA, A. V. V. de; SANTOS, U. S. dos; CORRÊA, R. M.; SOUZA, D. D. de; OLIVEIRA, F. J. V. de. Essential oil content and chemical composition of Lippia gracilis Schauer cultived in the sub-middle São Francisco Valley. Journal of Essential Oil Bearing Plants, v. 20, n. 4, p. $983-$ 994, 2017b.

SOUZA, A. V. V. de; SANTOS, U. S. dos; CARVALHO, J. R. de S.; BARBOSA, B. D. R.; CANUTO, K. M.; RODRIGUES, T. H. S. Chemical composition of essential oil of leaves from Lippia schaueriana Mart. collected in the Caatinga area. Molecules, v. 23, e2480, 2018.

SYED, Z.; LEAL, W. S. Mosquitoes smell and avoid the insect repellent DEET. Proceedings of the National Academy of Sciences, v. 105, n. 36, p. 13598-13603, 2008.

TONG, F.; COATS, J. R. Effects of monoterpenoid insecticides on $[3 \mathrm{H}]-\mathrm{TBOB}$ binding in house fly GABA receptor and 36Cl- uptake in American cockroach ventral nerve cord. Pesticide Biochemistry and Physiology, v. 98, n. 3, p. 317-324, 2010.

TRIPATHI, A. K.; PRAJAPATI, V.; AGGARWAL, K. K.; KUMAR, S. Toxicity, feeding deterrence, and effect of activity of 1,8-cineole from Artemisia annua on progeny production of Tribolium castanaeum (Coleoptera: Tenebrionidae). Journal of Economic Entomology, v. 94, n. 4, p. 979-983, 2001.

VONGSOMBATH, C.; PÅLSSON, K.; BJÖRK, L.; BORG-KARLSON, A. K.; JAENSON, T. G. Mosquito (Diptera: Culicidae) repellency field tests of essential oils from plants traditionally used in Laos. Journal of Medical Entomology, v. 49, n. 6, p. 1398-1404, 2012.

WANG, X.; HAO, Q.; CHEN, Y.; JIANG, S.;YANG, Q.; LI, Q. The effect of chemical composition and bioactivity of several essential oils on Tenebrio molitor (Coleoptera: Tenebrionidae). Journal of Insect Science, v. 15, n. 1, p. 1-7, 2015.

WEI, Q. B. Abamectin resistance in strains of vegetable leafminer, Liriomyza sativae (Diptera: Agromyzidae) is linked to elevated glutathione S-transferase activity. Insect Science, v. 22, n. 2, p. 243-250, 2015.

WERNECK, F. P.; COSTA, G. C.; COLLI, G. R.; PRADO, D. E.; SITES JUNIOR, J. W. Revisiting the historical distribution of seasonally dry tropical forests: new insights based on palaeodistribution modelling and palynological evidencegeb. Global Ecology and Biogeography, v. 20, n. 2, p. 272-288, 2011.

ZAPPI, D. C.; FILARDI, F. L. R.; LEITMAN, P.; SOUZA, V. C.; WALTER, B. M. T.; PIRANI, J. R.; MORIM, M. P.; QUEIROZ, L. P.; CAVALCANTI, T. B.; MANSANO, V. F.; FORZZA, R. C. Growing knowledge: an overview of seed plant diversity in Brazil . Rodriguésia, v. 66, n. 4, p. 1085-1113, 2015. 